\title{
Peoples, Homelands, and Wars? Ethnicity, the Military, and Battle among British Imperial Forces in the War against Japan
}

\author{
TARAK BARKAWI \\ Centre of International Studies, University of Cambridge
}

Ethnicity is increasingly central to analysis of war. ${ }^{1}$ Whether conceived in essentialist or constructivist terms, ethnicity is often accorded explanatory primacy in accounting for the organization and use of violence in wartime settings, in part due to the utility of processes of othering for group mobilization. Both the political and ideological context of hostilities as well as the motivations of combatants in the actual making of wartime violence are frequently conceptualized in ethnic and racialized terms. ${ }^{2}$ In a word, wartime violence is domesticated; it is seen as arising from the identities of, and commitments to, homelands.

This domestication of wartime violence involves two distinct and interrelated moves which together form an 'ethnic war complex.' ${ }^{3}$ The first is that ethnic identities provide the basis for the group formation necessary to large-scale, militarized violence. The second is that the willingness of such groups to kill

Acknowledgments: Thanks to James Brown, Susan Carruthers, Christopher Dandeker, John Game, Sudipta Kaviraj, Helen Kinsella, Ron Krebs, Mark Laffey, Louiza Odysseos, and two anonymous reviewers for comments. This research was supported by the SSRC-MacArthur Program on International Peace and Security and the College Research Fund, University of Wales, Aberystwyth. Guide to Archival Abbreviations in References: British Empire and Commonwealth Museum, Bristol-BEC; Gurkha Museum, Winchester-GM; Imperial War Museum, London-IWM; LiddellHart Centre for Military Archives, King's College, London-LH; National Army Museum, London-NAM; Oriental and India Office Collection, British Library, London-OIOC; Public Record Office, Kew-PRO.

1 Michael Brown et al., eds., Nationalism and Ethnic Conflict (Cambridge: MIT Press, 1997); Samuel Huntington, Clash of Civilizations and the Remaking of World Order (New York: Simon and Schuster, 1996); David Lake and Donald Rothchild, eds., The International Spread of Ethnic Conflict (Princeton: Princeton University Press, 1998). Cf. John Mueller, "The Banality of 'Ethnic War,'” International Security 25, 1 (Summer 2000), pp. 42-70.

2 Omer Bartov, Hitler's Army (Oxford: Oxford University Press, 1992); John Dower, War Without Mercy (London: Faber and Faber, 1986).

3 Tim Judah, Kosovo (New Haven: Yale University Press, 2000); Robert Kaplan, Balkan Ghosts (New York: St. Martin's Press, 1993). 
and sacrifice, as well as commit atrocity against racialized others, largely follows from their ethnic identity. Together the two moves are mutually reinforcing, and analyses indebted to this complex take similar form whether the group identity in question is attributed to ethnicity, modern nationalism, or even a 'civilization.' ${ }^{4}$ However, if military group formation cannot be reduced to ethnic or national identity, then it is considerably more difficult to account for wartime violence and atrocity by reference to such identities. If ethnic hatred does not supply the meaningful basis for violence, how do we account for the particularly savage nature of certain battlefields, such as those of the Eastern Front or the Pacific War?

Through study of the place of ethnicity in the organization and use of force in the multi-ethnic army Britain assembled to fight the Japanese in Burma in the Second World War, this essay develops an alternative understanding of the cultural constitution of military force and the making of wartime violence. One of the consequences of the pervasiveness of an ethnic imaginary in accounts of war is the systematic neglect of the transnational dimensions of military power. In the Second World War, the British Indian Army reached a strength of two million men. ${ }^{5}$ Together, Indians and Africans made up over two-thirds of the 'British' forces deployed in Burma, the largest land campaign fought by Japan outside of China in the Pacific War.

Imperial and other 'non-national' or foreign troops can serve as a critical vantage point on the ethnic war complex. In Burma, British Indian and African forces were to earn fighting reputations on the kind of savage battlefields that, elsewhere, have led scholars to invoke nationalism and racial ideologies. For troops in imperial service, nationalism could not define the warring sides nor can it provide the basis for social solidarity. What, then, were the relations between ethnicity and processes of group formation in imperial militaries? What light might that throw on military group formation more generally? Far from being the stable basis of group identity, ethnicity was reworked within processes of imperial military organization.

For the ethnic war complex, ethnic antagonism is assumed to be the basis of wartime violence, the willingness to kill and die. In Burma, however, where both sides generally refused to take prisoners and battlefield atrocities were common, the fighting generated more race hate than it initially required. Indian, African, and even British soldiers were largely ignorant of the Japanese until they met them in battle. This relation between war and ethnic antagonism is a reversal of the usual construction in which the latter is a cause of the former. How, then, are we to account for the intense and savage fighting that characterized the Burma campaign? Part of the answer is in fact to be found in processes of othering. But such processes were largely generic to wartime, military set-

${ }^{4}$ Victor Davis Hanson, Carnage and Culture (New York: Anchor Books, 2002).

5 F. W. Perry, The Commonwealth Armies (Manchester: Manchester University Press, 1988), p. 116. 
tings and did not generally require the kind of deep-seated racism in civilian society that Omer Bartov and John Dower have recourse to in accounting for the barbarities of the Eastern Front and the Pacific War respectively. Due to a variety of circumstances in Burma, an intensifying feedback loop of ever more savage fighting developed, generating an extreme antagonism often narrated by participants in racialized terms.

The first section below critically reviews the contrasting emphases placed on military and society in accounting for 'combat motivation' and outlines the arguments to follow. The second section deals with group formation, and provides an analysis of the organization of ethnicity in the British Indian Army. The third addresses the dynamics of battle in Burma and soldiers' representations of their experience. The conclusion returns to the theme of this introduction, that ready reference to an image of the world as composed of distinct and potentially antagonistic ethnic groups obscures the transnational dimensions of military organization and wartime violence. Arjun Appadurai notes that the "trope of the tribe" dominates our accounts "largely because forceful alternatives to it have yet to be articulated." 6 This essay seeks to contribute the basis of such an alternative for our understanding of wartime violence.

\section{SOCIETY, MILITARY AND BATTLE}

The essential proposition of the ethnic war complex is that group identities emanate from beyond military and wartime experience, yet enter into and fundamentally shape that experience. 'Pre-existing' ethnic or national identities, and their attendant constructions of friends and enemies, provide both the basis of group solidarity and the motivation to kill and sacrifice. The counter-proposition argued here is that the military, as well as campaigning and battle, comprise sets of historically variable structural relations which in large measure constitute the individuals and groups involved. The military and war are in part generative of the very identities which, in retrospect, appear to have motivated the combatants in the first place. The basis of this argument is that regular military service and the experience of combat are transformative. However, the cultural resources militaries draw on to make soldiers, as well as those soldiers fall back on to narrate their experiences, are derived from wider social context. Analysis must be sensitive to the nexus between society and military but not in the 'either/or' fashion that has characterized much of the debate over these issues.

War, and especially fighting, raise questions regarding the nature and sources of social solidarity. Fighting involves an armed clash between bodies of troops in which casualties are both suffered and inflicted. Vigorous and effective military service requires personal sacrifice, potentially of life, for group success

${ }^{6}$ Arjun Appadurai, Modernity at Large (Minneapolis: University of Minnesota Press, 1996), p. 161. 
and survival. The questions become what are the relevant groups and what are their social bases? Extant analysis in military history and sociology moves between two ideal typical answers to these questions. The first concerns the design and quality of military organizations and, in particular, their capacity for producing and sustaining closely-knit 'primary groups' of soldiers who fight for group survival in battlefield conditions. ${ }^{7}$ The relevant groups are soldiers' immediate comrades and the fighting formations of which they are a part. The second ideal type concerns the 'civilian' social and political context in which military organizations and their personnel are embedded. ${ }^{8}$ The relevant groups are a product of national, often racialized, constructions of friends and enemies.

This debate is profoundly shaped by its encounter with German armed forces in the Second World War and is in many ways unsatisfactory. While fighting for group survival is a central insight into the dynamics of battle, the idea of the 'primary group' risks overly psychologizing military organization. In their seminal article, Edward Shils and Morris Janowitz derived the 'primary group' from a particular Freudian conception of basic personality needs. As long as soldiers' immediate comrades and the unit of which they were a part continued to meet these needs, they would continue to fight. This approach can obscure the more general disciplinary and transformative capacities of military organizations. These capacities involve a wide range of social processes, including ritual relations as in drill; the dynamics of sacrifice and its representation as in the inculcation of regimental myth; and gender relations as in constructions of warrior masculinity.

The opposing emphasis on the social and political context of armed forces is also problematic. Reference to social context is often made to account for cases of savage and intense fighting and the widespread commission of atrocities, as in Bartov's Hitler's Army. One difficulty is that Bartov's polemic against 'primary group theory' and claim that German soldiers became "devoted believers in a murderous ideology" understate the role military organization and specific campaign experiences play in his own account. ${ }^{9}$ For example, the nature of the Russian Front, including the relatively primitive built environment, the harsh weather, and the Red Army's brutal use of its lavish manpower, worked to make Nazi racial categories particularly salient for German soldiers fighting in the East. Organizational factors such as increasingly uncompromising combat discipline, the failure to effectively prosecute war crimes, and the frequent severe lack of adequate clothing, shelter and food contributed significantly to soldiers' commission of atrocities and their depredations on the civilian population. As Bartov suggests, atrocities served in part as an outlet for the pressures

7 Edward Shils and Morris Janowitz, "Cohesion and Disintegration in the Wehrmacht in World War II," Public Opinion Quarterly 12, 2 (1948):280-315.

8 Bartov, Hitler's Army; James McPherson, For Cause and Comrades (New York: Oxford University Press, 1997).

9 Bartov, Hitler's Army, p. viii. 
confronting German soldiers, while Nazi ideology provided a convenient rationale for their behavior. The experiences of the German army in the East transformed it into 'Hitler's Army.'

There are further and more significant difficulties with Bartov's approach. For Bartov, the savagery and intensity of the fighting on the Eastern Front as well as the involvement of the army in atrocities and war crimes are indicative of the specifically Nazi social and political character of the army. This argument leaves analysts struggling to find functional equivalents of Nazi ideology to account for battlefield savagery elsewhere, such as the Yellow Peril for Americans in the Pacific War. Like Daniel Goldhagen's approach to the work of mass murder, Bartov requires the careful pairing of soldiers' racial and ideological commitments with their wartime objects of violence. ${ }^{10}$ Sadly, the history of warfare contains a surfeit of barbarity, transnational in scope, which defeats such an exercise. For example, a significant proportion of the mass killings in the occupied portions of the Soviet Union were carried out by foreign paramilitaries in German service. ${ }^{11}$ Such phenomena expose an important assumption in Bartov's work: that killing and violence are difficult for humans, who are not 'naturally dangerous' but must be transformed into killers through ideological indoctrination. This assumption easily leads to essentializing the identity of combatants as Nazis, racists, Serbs, Hutus, or whatnot, while correspondingly comforting the rest of us that absent such motivations, we would not participate in the extremes of wartime savagery.

Significantly, some analysts of violence and war have begun from the opposite assumption, that the military and wartime conditions bring out and encourage the 'killer in all men.' 12 This insight helps shift analysis away from the question of how the extraordinary motivations of particular individuals and groups overcome human pacificity. Instead, attention is redirected to the wider conditions which either encourage violence and allow it to run amok or prevent it from doing so. Rather than reducing battle and other wartime violence and barbarity to a question of participants' motivation, analysis focuses on the structural relations at work. In making this turn, it is not necessary to essentialize humans as either pacific or violent. Particular attributes and actions of participants in a battle emerge in the conflict situation itself, shaped but not determined by social background. Additionally, a structural approach enables the crucial distinction between the determinants of combatants' conduct or behavior, on the one hand, and how they might represent that behavior on the other. ${ }^{13}$

The Burma campaign was by no means the Eastern Front in terms of either 409.

10 Daniel Goldhagen, Hitler's Willing Executioners (New York: Vintage Books, 1997), pp. 383,

${ }^{11}$ Christopher Browning, Ordinary Men (New York: Harper Collins, 1992), p. 52; George Stein, The Waffen SS (Ithaca, N.Y.: Cornell University Press, 1966), p. 112.

12 Browning, Ordinary Men; J. Glenn Gray, The Warriors (New York: Harper and Row, 1970).

13 M. I. Gurfein and Morris Janowitz, "Trends in Wehrmacht Morale," Public Opinion Quarterly 10, 1 (1946), p. 79. 
the scale of the fighting or the casualties incurred, but it was, in the words of a historian who served there, "a very cruel war."14 The fighting exhibited many of the same features that characterized the island battlefields of the Pacific, where the fanaticism of the Japanese or the racism of the Americans, or both, are invoked in explanation. Yet, rather than a "spiritual clash between warrior representatives of two cultures," as Craig Cameron has characterized the fighting on Guadalcanal, the Allies were represented in Burma by an imperial army cobbled together from a variety of populations. ${ }^{15}$ The group identities of the Indian Army, which supplied the bulk of the troops, were neither simply reflective of indigenous ethnic relations nor based on Indian political entities or purposes. Nonetheless, Indian and African soldiers proved capable of holding their ground against and eventually defeating the determined infantry of the Imperial Japanese Army (IJA).

The next section focuses on the contingent and variable relations between ethnicity and group formation in the Indian Army. The following section takes up the question of battle. In the absence of established racialized constructions of friends and enemies among the imperial soldiery, why did battle in Burma take on such an intense and savage character? The analysis below is neither intended to establish that nationalism and societal racism play no role in savage battle nor could it. However, what follows outlines an alternative account of military group formation and the origins and character of savage battle, one which does not find in the 'trope of the tribe' a self-evident explanation, but rather refigures it as a technique employed by practitioners, and not always effectively.

\section{THE ORGANIZATION OF ETHNICITY IN THE BRITISH INDIAN ARMY}

Ethnicity is an apparently natural basis for group solidarity, both for scholars seeking to explain it and for professional officers seeking to create it. Many metropolitan and colonial armies utilized regional, 'tribal,' religious and local identities in fostering esprit de corps. The Indian Army was no exception. But just what role did ethnicity play in processes of group formation?

In reference to a much earlier period of British involvement in India, John Lynn argues that South Asian culture and religious norms underpinned the loyalty and morale of British Indian troops: "be not misled by the British red coat of the sepoy; beneath it beat the heart of India." 16 But for Stephen Rosen, British Indian armies were effective "due to a form of military organization that increased the cohesion of the army by divorcing it from society," which he conceives as riven by caste divisions. ${ }^{17}$ These two perspectives conceive ethnicity

14 Louis Allen, Burma (London: J. M. Dent \& Sons, 1984), p. xviii.

15 Craig Cameron, American Samurai (Cambridge: Cambridge University Press, 1994), p. 104.

16 John Lynn, "Heart of the Sepoy," in Emily Goldman and Leslie Eliason, eds., Diffusion of Military Knowledge, Technology and Practices (Stanford: Stanford University Press, 2003), p. 62.

17 Stephen Rosen, Societies \& Military Power (Ithaca, N.Y.: Cornell University Press, 1996), p. 196. 
as fixed and given by civilian society. In the first, civilian identities underwrite military service; in the second, the military is cordoned off from the ethnic differences of civilian society. But as British rule continued and deepened, it played an increasing role in constructing Indian communal identities, a process in which the Indian Army and its 'martial races' came to be closely bound up. ${ }^{18}$

As such, analysis must address the ways in which ethnicity was both incorporated into, and transformed by, the Indian Army. ${ }^{19}$ Through 'martial races' discourse, military officials sought administratively to order India's diverse populations into clearly differentiated categories of caste, religion, and region. Only on this 'official' basis were communal identities incorporated into military organization. Ethnicity, however, proved far more flexible in processes of group formation than either the ethnic war complex or 'martial races' discourse allows. Rather than being the basis for group formation, ethnicity provided mutable resources for organizing difference.

By the time of the World Wars, the Indian Army was composed of a variety of ethnic 'classes,' or 'martial races.' British officials believed that each 'class' of troops reflected a distinct ethnic group in Indian society. ${ }^{20}$ They sought to oppose one to the other in the army. The idea was to foster group spirit through friendly rivalry and competition among units and to avoid the kind of cultural homogeneity that was seen as in part responsible for the mutiny and rebellion of $1857 .{ }^{21}$ However, in practice it was necessary to use the disciplinary capacities of military organization to ensure the men lived up to the official image of their religions and cultures. Before divide et imperia could be applied to the Indian Army, distinct ethnic groups had first to be invented and constituted through a variety of boundary drawing practices.

The discussion below outlines how ethnicity was incorporated into the Indian Army, its role in patterns of resistance and discipline, and the ways in which, despite deliberate reinforcement, ethnic difference was often overcome in conditions of wartime military service. As will be seen, ethnicity could be emphasized in group formation or played down; it provided symbolic resources for resistance as well as obedience; and ethnic difference proved no obstacle to group formation when soldiers were placed in common conditions and shared experiences.

\section{The 'Class' Organization of the Indian Army}

'Class' organization was derived from 'martial races' discourse, which was based on a distinction between those populations considered to possess martial

18 Nicholas Dirks, Castes of Mind (Princeton: Princeton University Press, 2001); Gyanendra Pandey, The Construction of Communalism in Colonial North India (New Delhi: Oxford University Press, 1990).

19 Seema Alavi, The Sepoys and the Company (New Delhi: Oxford University Press, 1995).

20 Philip Mason, A Matter of Honour (London: Jonathan Cape, 1974), ch. 14.

21 Stephen Cohen, The Indian Army (Berkeley: University of California Press, 1971), ch. 2. 
qualities and those which were not. ${ }^{22}$ While the notion that certain populations were suited for military service had a basis in the caste system, the distinctions involved reflected British constructions of Indian society. In classifying populations through shifting combinations of physique, place, and culture, 'martial races' discourse participated in constructing boundaries between groups. ${ }^{23}$ It did so in part simply through restricting recruitment to the favored minority populations, while also ensuring that once in service recruits conformed to the British image of their indigenous culture.

Regardless of their artificiality, martial categories had real consequences in terms of access to employment in the army. By the Second World War, the Indian Army had been recruiting many of its favored classes for almost a century. The communities from which the soldiers were recruited were shaped by the cultural experience as well as the financial benefits and political access of military service. The Sikhs, for example, were defined as a recruitable group by religion and caste, the warrior dimensions of which were then emphasized over others. The scale of Sikh employment in the army during the Raj further influenced the development of Sikhism in martial directions. ${ }^{24}$ Regimental traditions, rituals, and uniform played a role in this along with the circulation of Sikh men between barracks and village. Officers put considerable effort into ensuring that Sikhs in service conformed to a British image of what the 'pure' Sikh was like. As one British commander of a Sikh company wrote home, "The Sikhs have many religious customs; we see that they keep them whether they like it or not." 25

Most Indian Army infantry battalions were organized on a "class-company" basis. Each company was generally of a different ethnicity, such that a battalion might have a company of Sikhs, one of Dogras, one of Pathans, and one of Punjabi Muslims. A company would be headed by a commissioned officer, always British until the interwar period, assisted by Viceroy Commissioned Officers (VCOs). VCOs were an intermediate class of officer promoted from the ranks who mediated between the commissioned officers and the men. The VCOs in each company were usually of the same class as the men, and British officers were expected to know the native language of the class they commanded as well as the army lingua franca, Urdu. At the battalion level, senior VCOs, who ideally had the respect and confidence of all the classes in the unit, would aid the battalion commander in maintaining good relations among the various classes. It was important for morale that promotions and other goods were equally shared. The long-service nature of the Indian Army meant that bat-

22 Omissi, The Sepoy and the Raj (London: Macmillan, 1994), ch. 1.

${ }^{23}$ Bernard Cohn, Colonialism and Its Forms of Knowledge (Princeton: Princeton University Press, 1996); Thomas Metcalf, Ideologies of the Raj (Cambridge: Cambridge University Press, 1995).

${ }^{24}$ Cohn, Colonialism and Its Forms of Knowledge, pp. 106-11; Omissi, The Sepoy and the Raj, pp. $94-99$.

25 Hannah Cohen, Let Stephen Speak (London: Sylvan Press, 1943), pp. 116-17. 
talions often had great stability of personnel, and in a good battalion experienced officers and VCOs would know and trust one another, having served many years together in various capacities.

A basic feature of the class organization of the army was the reinforcement of ethnic difference. Peter Gadsdon, a wartime officer in $4 / 14^{\text {th }}$ Punjab, new to the Indian Army, learned about the "foibles" of each class while his battalion trained for service in Burma: "A Company, the Sikhs, grew their hair long and never cut it during their lifetime ... [They] also do not smoke, and to offer them a cigarette is an insult. B Company were Dogras, many of them Hindus of the high Brahmin caste. The Cow is a sacred animal to all Hindus, and they were very careful in their eating and drinking habits . . . My Punjabi Mussulmans in C Company held that all pork was defiled and the more strait-laced of them would not touch alcohol. D Company Pathans were also Muslims and held the same views, but, in their case, it was easy to upset them over their honour, about which they could sometimes be touchy."26

Cultural differences among the classes were reinforced in numerous ways including uniform, religion and diet. Battalions in garrison maintained holy men for each religion represented in its ranks, who would hold separate services for the Sikh, Hindu, and Muslim companies. Religion was woven into the fabric of discipline, making any deviation from religious precepts difficult for individuals, while violations of military discipline became a religious matter.

The Indian Army used diet and mealtime rituals to maintain difference as well as to integrate formations. In an infantry battalion, each class would prepare its own particular cuisine in ways which respected religious and caste dictates, eating in separate messes. As Bruce Lincoln notes, there is nothing "more conducive to the integration of society than the ritual of sharing food." 27 Not only are bonds of sentiment and obligation established among those who share the meal, but a rigid boundary is drawn between them and those who do not.

In accounts of relations between military and society, analysts construct the significance of civilian ethnic difference for military service differently. Some argue that if militaries reflect the ethnic divisions of civilian society, they will lack the cohesion needed for combat. ${ }^{28}$ Others see the military, due to its rigid disciplinary structure and capacity to transform individuals, as a potential agent of social change, capable of overcoming ethnic prejudice in the ranks through leadership, incentives, and punishments. ${ }^{29}$ Both these arguments reflect the historical experience of different military institutions. What is crucial is the par-

26 Peter Gadsdon, An Amateur at War, unpublished ms., p. 29.

27 Bruce Lincoln, Discourse and the Construction of Society (Oxford: Oxford University Press, 1989), p. 88.

28 Rosen, Societies and Military Power. See also Alon Peled, A Question of Loyalty (Ithaca, N.Y.: Cornell University Press, 1998)

29 Sherie Mershon and Steven Schlossman, Foxholes \& Color Lines (Baltimore: The Johns Hopkins University Press, 1998); Charles C. Moskos and John S. Butler, All that We Can Be (New York: Basic Books, 1996). 
ticular way in which a military organizes ethnic difference and how it structures the salience that difference has for soldiers. In explicitly seeking to foster ethnic distinctiveness in its infantry battalions, the Indian Army ensured that ethnicity was a basis for group formation in military life, in ways both productive and corrosive of discipline and fighting spirit.

\section{Ethnicity, Resistance, and Discipline in the Indian Army}

In creating ethnically distinct units, the British made space for each class to organize resistance on the basis of caste and religion and for the men to draw on their communal ties in doing so. Caste could be invoked to avoid distasteful jobs, whether through conviction or calculation. After the 1935 earthquake in Quetta, the $4 / 19^{\text {th }}$ Hyderabad was sent to bury corpses and its high caste company of Kumaonis refused to touch the dead on grounds that it would break their caste, relenting only when British and Indian officers, among them a Brahmin, set to work first as an example. ${ }^{30}$ While this affair was localized, the communal organization of the army made it easy for trouble to spread.

In the early period of the war, there were a number of instances of unrest in Sikh units. ${ }^{31}$ The Sikhs made use of the potent symbol of the Sikh turban as a mechanism for organizing resistance. Any Sikh who wore his steel helmet could be seen to have violated his religion. Grievances that might be local in nature could easily involve other troops of that class through use of religious and communal symbols. An important factor underlying unrest in Sikh units, especially those about to embark for overseas service, was tension in the Punjab arising from the Muslim League's goal of an independent Pakistan. Worried that the situation would turn violent, as it eventually did, the Sikhs were concerned they would be unable to protect their families. The communal organization of the army created space for communal politics to disturb discipline.

However, the manner in which the army was organized shaped the way communalism asserted itself. Most men in the infantry battalions served alongside others of their caste, religion, and region, sharing common conditions and making such identities an obvious basis for organizing resistance. Each regiment recruited from particular regions, and recruits often had a variety of local ties with one another and other serving soldiers. Informal groups in the ranks were often based on these 'sub-class' local relations. ${ }^{32}$ Even so, once organized in classes, class took on great salience for the troops concerned, as each class sought to protect its position with respect to promotions and other perks and benefits. Class had a significance for the everyday life of soldiers over and above the communal differences of Indian society due to the fact that the army

${ }^{30}$ Humphrey Evans, Thimayya of India (New York: Harcourt, Brace, and Co., 1960), p. 151.

31 OIOC, L/WS/1/303, Disaffection of Sikh Troops; OIOC, L/WS/2/44, Note on Sikhs; PRO, WO 208/763, Indian Army Morale: Mutinies and Cases of Indiscipline.

32 Namrata Narrain, Co-option and Control, Ph.D. Dissertation, University of Cambridge (1992), pp. 118-19; Omissi, The Sepoy and the Raj, pp. 88-90. 
was organized in class terms. It was thus a primary basis for group formation and competition in units, but not one which simply reflected distinct ethnic groups in civil society.

For example, there was an important difference between the role caste played in the army as opposed to Indian society. In civil society, despite the local variety and fluidity in caste relations, castes were generally hierarchically ordered. However, in the army, it was vital for discipline and morale that even though caste differences were respected, all castes had to be treated equally. Each class in a battalion, regardless of its relative position in the hierarchies of colonial Indian society, had to be handled on an equivalent basis.

Classes in a battalion were acutely sensitive to issues of fairness in terms of promotions, perks, and the assignment of difficult duties. The NCOs and VCOs of each class or sub-group would protect the interests of their troops. New officers in the Indian Army were warned about "bhai bundi," or 'brotherhoodliness,' the idea that men with village or kinship ties will watch out for one another. $^{33}$ There were frequent charges of nepotism, favoritism as well as graft organized on a class or sub-class basis. ${ }^{34}$ VCOs would seek to ensure that men from their family, village, or community were promoted. ${ }^{35}$ In peacetime, the presence of experienced officers who spoke their men's language and long service VCOs ensured that such troubles were kept to a minimum. The stability of class composition in the peacetime army also meant that it was relatively easy to treat each class fairly, as the proportion of classes in a unit rarely changed, ensuring an equivalent number of NCO and VCO positions for each class.

During the Second World War, the manpower pressures of expansion led to the recruitment of new classes and their insertion into formations composed mainly of pre-war classes, producing numerous problems centered around tensions and rivalries between classes. Classes sometimes had to be mixed together in the same companies. There was an overall decline in the quality and experience of battalions' personnel as the proportion of regular pre-war officers and VCOs dropped. The problems that resulted in these cases had less to do with the communal tensions of Indian civil society, although these played a role, than with the ways in which the fixed ethnic categories of the Indian Army were disrupted by upheaval in wartime personnel policy.

In the $10 / 16^{\text {th }}$ Punjab, the proportions of Sikhs, Muslims, and Hindus had to be altered due to difficulty recruiting Dogras and Sikhs, increasing the percentage of Muslim troops. As a consequence, Sikh/Muslim tensions ran high in the unit and involved theft of arms. The number of Sikh NCOs and VCOs

33 OIOC, L/MIL/17/5/2225, Four Lectures by a Commanding Officer for Officers Joining the Indian Army, Lecture IV.

34 Evans, Thimayya of India, pp. 195-56; NAM, 8206-83-20, Tighe Papers, "Balance of Power."

35 See, for example, LH, Brig. A. B. Gibson, 1/4, Unofficial War History, 2/13 Frontier Force Rifles, p. 65; Robin Schlaefli, Emergency Sahib (London: R. J. Leach \& Co., 1992), p. 78. 
dropped with the proportion of Sikh troops, and the chances of the remaining Sikhs for promotion declined, further contributing to Sikh grievances. ${ }^{36}$ Similar problems arose in the $4 / 14^{\text {th }}$ Punjab. Prior to going to Burma, they were unable to find enough recruits of the right class to fill out their Sikh and Dogra companies. They made up numbers with Jats in the Sikh company and Gujars and Ahirs in the Dogra company. It had been intended to put these new classes in their own platoons under their own VCOs, but because these classes had not previously been recruited in the army, "the men were far too junior to hold any thing but lower rank appointments." They were spread out among the Sikhs and Dogras: "[i]t was almost inevitable this ended in the greatest dissatisfaction." 37 The new classes were shunned, particularly in the Sikh company, having no VCOs to look out for their interests, and eventually became "surly and unwilling to fight." 38 In other battalions, too, minor trouble arose in companies composed predominantly of one class 'victimizing' other classes who were temporarily making up numbers. ${ }^{39}$

In a closed social space such as a battalion, individuals affiliate with groups capable of seeing to their interests and needs. Such informal groups have differential capacities to protect their members and victimize others in part determined by the authority structure of the unit. While in the Indian Army group formation was facilitated by communal identities, informal groups of this kind are found in all militaries and similar institutions, such as prison camps. ${ }^{40}$ Patterns of group formation can be altered by commanders who restructure the capacities of such groups to protect their members or victimize others.

For example, the kind of minor trouble described above could be averted by different handling of relations between class groups. The $2 / 13^{\text {th }}$ Frontier Force Rifles faced the problem of promotions among newly recruited classes but avoided any trouble through promoting men of the new classes despite their short service. "The old classes did not approve originally, but, when told that the promotions would go on no matter how much they moaned about numbers being cut, soon shut up." ${ }^{41}$ In this unit, command ensured that ethnic organization did not have a negative bearing on the everyday life of the new soldiers and so it did not become a disciplinary problem.

Even though class organization was a cause of trouble, it was simultaneously a source of discipline, especially in the hands of officers who knew how to manipulate it. Many Sikhs, for example, realized that the spate of desertions and minor mutinies in the early years of the war might give their class a bad

36 OIOC, L/WS/2/44, Note on Sikhs.

37 IWM, 78/6/1, Gadsdon papers, "War History of the $4^{\text {th }}$ Battalion of the $14^{\text {th }}$ Punjab Regiment $1939-45, "$ p. 59.

38 IWM, 78/6/1, Gadsdon papers, untitled memoir of his wartime service, p. 129.

39 NAM, 8206-83-20, Tighe Papers, "The Balance of Power."

40 Samuel Meyers and Albert Biderman, eds., Mass Behavior in Battle and Captivity (Chicago: The University of Chicago Press, 1968).

${ }^{41}$ LH, Brig. A. B. Gibson, 1/4, Unofficial War History, 2/13 Frontier Force Rifles, p. 73. 
name and lead to a reduction of their presence in the army, on which Sikh communities depended for their livelihood. One Sikh soldier in the 10/12 $2^{\text {th }}$ Frontier Force Rifles entraining for service in the Middle East told a British officer, "[w]e are thoroughly ashamed of desertions that have taken place amongst Sikhs, and it is our intention to wipe out the disgrace." 42

Class disaffection could be turned into fighting spirit. In the demoralized Jat company of the $8 / 19^{\text {th }}$ Hyderabad, there were tensions between two sub-classes of Jat, those from East Punjab and those from Uttar Pradesh, aggravated by VCOs who sought to assert the interests of their respective sub-classes. The battalion commander, Lt. Col. Thimayya, played upon the Jats' sense-as a company - of their warrior prowess vis-à-vis the other companies. Soon the Jats "wanted to be used in an important action so that their bravery would be proved." When the opportunity came, Thimayya told them they now had a chance to vindicate themselves: "I ordered a bayonet charge. That morning the Jats went wild." Afterwards, they were "exuberant." 43 The articulation of class honor with warrior masculinity trumped, as it were, communal tensions among the Jats, subsuming two group identities with a third. From Thimayya's point of view, he had created a virtuous cycle in which each company would seek to outdo the others on the battlefield. Here, rather than being a source of trouble, class became a source of élan.

As can be seen, it was neither military organization nor the communal divisions of civilian society which alone was responsible for the disciplinary problems and benefits arising from class organization. What was important was the particular, often local manner in which the Indian Army incorporated, shaped, and conditioned ethnic difference.

\section{Overcoming Ethnic Difference}

The term 'ethnicity' denotes the nearly infinite elasticity of religion, culture, language, place, and bodily characteristics in the making and unmaking of social groupings. As Lincoln comments, such groups are composed "of people who feel bound together as a collectivity and, in corollary fashion, feel themselves separate from others who fall outside their group." 44 Not only are such groups continually in the process of being remade through the evocation of relations of affinity and estrangement, but new groups can be constructed which may encompass previous groups or split them apart. The flexibility of ethnicity is apparent in the ways in which the British created fixed ethnic categories for their troops, who were then required to alter their practices to fit categories ostensibly based on their own civilian identities. But as easily as military service could inscribe ethnic difference, it could also unmake it. In the $2 / 13^{\text {th }}$ Frontier Force Rifles, Jats who had temporarily made up numbers in the Sikh com-

\footnotetext{
42 OIOC, L/WS/2/44, Note on Sikhs. $\quad{ }^{43}$ Evans, Thimayya of India, pp. 202, 211, 222.

44 Lincoln, Discourse and the Construction of Society, p. 9.
} 
pany offered to convert to Sikhism in order to remain with the battalion. ${ }^{45}$ Ethnicity was indeterminate in defining social groupings. Common conditions and shared experience were more significant.

In the support branches of the Indian Army, as well as in many African formations, ethnicity was organized in ways which successfully broke down difference. Even in the class-company infantry battalions of the Indian Army, the nature of everyday life in the military, especially in wartime, often served to overcome difference. Additionally, ethnic difference in sub-units could be used to create cohesiveness and excellence in higher formations through competition, as in the example from Colonel Thimayya's battalion. Ethnicity was not the only basis for identity in the Indian Army. Military unit identities offered other, overlapping bases.

In the Indian Army, it was official policy to maintain ethnic difference, even when soldiers were desirous of overcoming difference. While British officers often thought that Indians would serve in the army only if their religion and caste were respected, there is much evidence to the contrary. During the Second World War some British officers became aware that they were more insistent on the maintenance of caste and religion than their troops. The commander of an engineer company in the $10^{\text {th }}$ Indian Division noted with surprise that many of his men were in favor of breaking down caste restrictions, citing instances in which food which violated caste was eaten voluntarily: "Prewar NCOs and VCOs are apt to be still a little strict not I think alive to genuine religious feeling but to a 'diehard' sense that the Corps always has been run that way and any change is contrary to "standing orders." "He concluded that "established Corps customs are in retard of contemporary feeling and are restricting any progress." 46

Many subsidiary branches of the army 'mixed' rather than separated classes of troops, as did the Royal Indian Navy and the Royal Indian Air Force. The Indian Observer Corps, for example, mixed all classes of Hindus together without trouble and used Punjabi and other Muslim troops as cadre for units recruited in Assam and South India with no difficulties arising from religion or caste. ${ }^{47}$ The assumption had been that classes would not mix due to their own prejudices, but experience proved otherwise: "The Recruiting Directorate points out that that the pre-war idea that classes would not mix in the Army was erroneous. Vested class interests, bogus caste prejudices, and parochial minded [British Officers] and V.C.O.'s [sic] have endeavored unsuccessfully to maintain the narrow class composition on which most of the pre-war Army was based." 48 One engineering unit purposely made its soldiers do something to de-

45 LH, Brig. A. B. Gibson, 1/4, Unofficial War History, 2/13 Frontier Force Rifles, p. 73.

46 OIOC, L/PJ/12/655, Middle East Military Censorship Fortnightly Summary Covering Indian Troops, No. CL, 16-29 June, 1943.

47 OIOC, L/R/5/273 War Department History, Expansion of the Armed Forces in India, Supplement No. 1, Oct. 1943-Mar. 1944, p. 10.

48 OIOC, L/R/5/273 War Department History, Expansion of the Armed Forces, Sept. 1939Sept. 1943, p. 32. 
file their caste and religion, such as work with leather or eat prohibited foods. The men messed together and there were no reported communal tensions. ${ }^{49}$ This unit created cohesion by breaking down rather than maintaining difference, placing everyone in common conditions.

Dietary restrictions were frequently violated in practice. Especially on active service, it sometimes became necessary for Hindus to eat beef or for vegetarians to eat meat simply because other rations were unavailable. Generally in such cases, it was possible to violate dietary restrictions without resistance from the men, although sometimes officers deceived troops as to what they were in fact eating out of their own fears that the men would reject the food. ${ }^{50}$

While mealtime rituals generally replicate social divisions and hierarchies, there are possibilities for meals to "serve as the instruments with which alternatives are posed to the established order." 51 In the branches of the Indian Army which mixed classes together, the common mess was an important site for overcoming ethnic difference. There are also examples from infantry units. Captain Sahgal recounts instances in which he arranged for the Hindu and Muslim VCOs of his battalion to dine together. For Sahgal, separate messes illustrated the "unnatural barriers which had been built up in the Indian Army to keep Hindus and Muslims apart." 52 The various violations of dietary rituals reveal the flexibility of caste and religious practices with respect to military organization. The army created the sense that meals had to be taken separately by rigidly maintaining difference. However, through leadership, as in Sahgal's case, or necessity, as on active operations, apparently fixed barriers crumbled relatively easily.

The mutability of ethnicity with respect to military service is apparent also in the East and West African forces. Although recruitment was largely determined by which 'tribes' were considered martial, distinct ethnic identities were not officially maintained and reinforced in service. Rather than separating men into ethnically differentiated platoons or companies, they were generally mixed together. Civilian ethnicity simply did not have the same salience in the bulk of the East or West African forces because they were organized differently. ${ }^{53}$

Higher formations offered another level at which soldiers could identify irrespective of ethnicity. A regimental or other unit identity could be interposed between soldiers and the differences of civil society. ${ }^{54}$ While the companies of a battalion in the Indian Army might be divided by ethnicity, they would all share the same regimental identity.

49 BEC, Oral History Archive, Tape No. 319, Lt. Col. Geoffrey Pawle.

50 OIOC, L/MIL/17/5/2239, Jungle Jottings, "Food and Fitness"; Evans, Thimayya of India, pp. 204-5; John Shipster, Mist Over the Rice Fields (Barnsley: Leo Cooper, 2000), pp. 86-87, 96.

${ }^{51}$ Lincoln, Discourse and the Construction of Society, p. 88.

52 Peter Ward Fay, The Forgotten Army (Ann Arbor: University of Michigan Press, 1993), pp. $55-56$.

53 Timothy Parsons, The African Rank-and-File (Portsmouth: Heinemann, 1999), pp. 5, 55.

54 Fay, The Forgotten Army, p. 26; John Masters, Bugles and a Tiger (London: Michael Joseph), pp. 137-39. 
This section has dealt with the first half of the ethnic war complex, the role of ethnicity in processes of military group formation. Despite the essentialist ethnic principles that governed Indian Army organization, ethnic relations were constructed in the course of organizational processes and their interaction with social context. Rather than being the basis for group formation, ethnicity provided mutable resources for the military organization of difference. How a military structures the salience that ethnic difference has for soldiers is a crucial component in group formation and the production of identity.

The next section deals with the second half of the ethnic war complex, the question of the meaningful basis for wartime violence and the putative role of racialized constructions of self and other. In common with the arguments made above, it will argue that for combat troops the relevant identity constructions are largely generated within the military and campaign context, rather than being pre-given by civilian society.

\section{BATTLE AND REPRESENTATION IN BURMA}

It is commonly observed in military sociology that 'multi-ethnic' armies are not as effective in combat as 'national' ones. ${ }^{55}$ Certainly the class organization of the Indian Army created tremendous administrative difficulties in replacing heavy losses in the correct class proportions. Nonetheless, the Indian Army proved itself in battle, with many of its formations - such as the $4^{\text {th }}$ Indian Division-earning very tough reputations against first-class opponents. In the Far East, the Indian Army initially suffered severe defeats in Malaya, Singapore, and Burma where its battalions were composed in large measure of new recruits, the pre-war regulars having already been sent to North Africa and the Middle East. However, from 1943, Indian, African, and British forces in Burma and Northeast India, under the command of Sir William Slim's $14^{\text {th }}$ Army, began to stiffen. In 1944, they repulsed a major Japanese offensive at the decisive battles of Imphal and Kohima and shortly thereafter they began their successful reconquest of Burma.

The fighting in Burma was brutal by the standards of the Second World War. Refusal to accept surrender was the norm for both sides. Enemy wounded were generally killed out of hand. Atrocities were common and included the abuse, torture, and killing of those who did manage to surrender. Japanese mistreatment of Allied POWs is well-known but Japanese soldiers who surrendered, or tried to, faced widespread mistreatment. ${ }^{56}$ What the fighting lacked in scale (as

55 W. D. Henderson, Cohesion the Human Element in Combat (Washington, D.C: National Defense University Press, 1985), pp. 26, 76; Shils and Janowitz, "Cohesion and Disintegration," p. 285.

56 Burma was very much like other Pacific War battlefields with respect to the savagery exhibited by both sides. See, for example, Yuji Aida, Prisoner of the British (London: The Cresset Press, 1966), pp. 48-52; Allen, Burma, pp. 183, 295-96, 588 n. 2; Robert Edgerton, Warriors of the Rising Sun (New York: W. W. Norton, 1997), ch. 9; Ian Lyall Grant and Kazuo Tamayama, Burma 1942 (Chichester: The Zampi Press, 1999), p. 91; Sir William Slim, Defeat into Victory (London: 
compared to that in Europe), it made up for in intensity and savagery. ${ }^{57}$ The commander of an Indian division reported of his first experiences with the Japanese that "The Jap is a 'killer' and he does not mind being killed . . . The fighting therefore is always at a remarkably 'intense' tempo." 58 A British officer who fought in Europe and Burma commented of one engagement, "I would go through the whole campaign in Europe again rather than that 7 days in Sangshak. The tempo and fierceness of the fighting did not compare."59

It is in conditions of savage fighting and barbarity that scholars have explanatory recourse to national identities and racial ideologies. For the ethnic war complex, ethnic identities, and the constructions of self and other they entail, account for wartime violence. The racial prejudices of national societies are manifest on the battlefield. Battlefield conduct is evidence of an identification of the common soldier with the nation, racial ideology, and the legitimation of political authority more generally.

Students of the Pacific War have had little difficulty in finding the most extreme racism among the personal and official accounts of Allied soldiers, and the Burma campaign is no exception. ${ }^{60}$ A British general noted of the Japanese that they "are in fact highly efficient and completely ruthless barbarians and, as the Chinese have long ago discovered a policy of complete extermination is the only one possible." 61 But the fact that the fighting is represented by participants in racist, and here even exterminationist terms is not the last word in the matter. Certainly racist constructions provided a language through which combatants could make meaningful their experience of war, whether during or after the fact. However, that for many soldiers such constructions were developed in the course of the fighting should inspire caution in assessing the role of ethnic antagonism in the making of wartime violence. ${ }^{62}$ Battle, like military organization, sets in train its own cultural processes. Soldiers' representations should be interpreted less as reports of their inner motivation than as partial descriptions and efforts to make meaningful sense of a structural context common to both sides.

The discussion below begins by using the problem of surrender in Burma to illustrate both how the structure of battle shaped and conditioned the behavior of participants, and how it generated feedback loops that intensified the fight-

Cassell, 1956), pp. 73, 188; Philip Stibbe, Return via Rangoon (London: Leo Cooper, 1995), p. 88 and Part III.

57 LH, General Sir Douglas Gracey, 2/24, Suggestions for Training for and Conducting War against the Japanese for Troops who have been Fighting in European Theatres of War, p. 6.

58 PRO, WO 203/5716, Lessons of the Burma Campaign, 1942, April-May, preamble, par. F.

59 OIOC, Mss. Eur CO770, Victor Brookes, "Games and War," p. 5.

${ }^{60}$ Dower, War Without Mercy; Eric Bergerud, Touched with Fire (New York: Penguin Books, 1996); Cameron, American Samurai; Mark Johnston, Fighting the Enemy (Cambridge: Cambridge University Press, 2000), Part II.

${ }^{61}$ LH, Lt. Gen. Thomas J. Hutton, 3/16, "Operations in Burma," p. 53.

62 Gerald F. Linderman, The World within War (New York: The Free Press, 1997), ch. 4. See also Edgerton, Warriors of the Rising Sun, pp. 315-18. 
ing. At the same time, as Allied soldiers cited Japanese refusal to surrender or accept surrender as evidence of irredeemable otherness, they began to behave in very similar ways. There was a convergence of patterns of battlefield conduct among the antagonists regardless of their origins or on which side they fought. The discussion then turns to participants' narrations of battlefield experiences, showing how the battlefield context in combination with official propaganda generated racialized representations of self and other.

\section{The Problem of Surrender}

Wherever the Japanese were encountered in battle, what most astonished Allied soldiers was their determination to die rather than surrender. As Charles Carfrae wrote of his experience on Chindit operations: "The Japanese - those hobgoblins of the forest, the enemy - were beyond easy reach of our imagination. They were men, of a sort, of course, but men totally alien ... giving no quarter and expecting none ... However hopeless his position, or no matter how severely he was wounded, it was almost unheard of for a Japanese soldier to throw in his hand." 63 In Burma, the last act of many a cornered Japanese soldier was to clasp a grenade to his stomach and detonate it. ${ }^{64}$ Typically, Allied soldiers explained this behavior by reference to their own version of the ethnic war complex, emphasizing the peculiarities of Japanese culture and the ways in which the cult of the Emperor was woven into the discipline of the IJA. ${ }^{65}$

As with Western militaries prior to World War I, Japanese doctrine emphasized overcoming weight of firepower through 'spirit.' A very harsh training regime, firm discipline, and extensive indoctrination of junior officers played important roles in the inculcation of offensive spirit. ${ }^{66}$ Certainly these factors were in part responsible for the extraordinary determination of Japanese troops to fight to the 'last man, last round.'

There were, however, additional reasons for this behavior. Japanese soldiers were told by their own command that the Allies would horribly mistreat and kill them if they surrendered. ${ }^{67}$ Such warnings were not wholly misplaced. It is impossible to verify the numbers and the evidence is partly anecdotal but many Japanese prisoners were killed out of hand by British and imperial troops. This often happened immediately after capture while the POWs were in the hands of frontline infantry troops being escorted rearwards, or when Japanese soldiers

63 IWM, 80/49/1, Charles Carfrae, "Dark Company,” p. 128. See also: Bergerud, Touched with Fire, pp. 124-45; Bernard Fergusson, The Wild Green Earth (London: Collins, 1946), ch. 9; Linderman, World within War, pp. 163-67; IWM, AL5304, Mentality of Japanese Soldiers, Minutes of the Meeting at Chatham House, 8 Sept. 1948.

64 John Nunneley and Kazuo Tamayama, eds., Tales by Japanese Soldiers of the Burma Campaign (London: Cassell, 2000), no. 56; Gadsdon, An Amateur at War, pp. 75-76.

65 Shipster, Mist Over the Rice-Fields, p. 4.

66 Bergerud, Touched with Fire, pp. 124-45; Edgerton, Warriors of the Rising Sun.

67 OIOC L/MIL/17/20/25, Periodical Notes on the Japanese Army 1942-44, No. 1 General Characteristics, Morale and Training. 
were trying to surrender. ${ }^{68}$ On at least two separate occasions, Indian soldiers mass murdered captured wounded Japanese, immolating 120 in one incident and burying alive between twenty and fifty in another. ${ }^{69}$ British and imperial soldiers who carried out such acts could justify them by reference to the wellknown Japanese mistreatment of Allied prisoners. ${ }^{70}$

However, there were relatively few Japanese prisoners for British and Imperial troops to mistreat or murder. Aside from the IJA's fighting spirit, a significant reason for this was that it was common practice to kill every Japanese on the battlefield itself. As Gian Singh wrote in his poem "Kohima," a battle in which he fought:

No prisoners we took, no mercy we gave

Their crimes against comrades we never forgave. ${ }^{71}$

Offering no quarter was justified by the notion that all Japanese were dangerous until dead. ${ }^{72}$ An operations research report from the first Chindit operation noted in their first engagement some apparently dead Japanese springing back to life to shoot some British troops in the back. From then on it became "universal practice to put a round or a bayonet into any Jap not obviously dead . . . This undoubtedly resulted in many potential prisoners being killed, but it was a very necessary practice." 73 The report notes that the Japanese did the same to Allied dead and wounded. Such stories of Japanese treachery, which have counterparts on other Pacific War battlefields, were widespread among combat troops and served to justify similar, reciprocal actions. ${ }^{74}$ After a British officer was killed by a Japanese soldier feigning death, his friend wrote "We found out then what we were never afterwards to forget-it doesn't pay to leave wounded Japs breathing."75

That British and imperial troops generally left no Japanese alive on ground they occupied goes some way towards accounting for a feature of Japanese battlefield behavior that did not square with their legendary 'fanaticism.' It

68 Slim, Defeat into Victory, p. 327; LH, General Sir Douglas Gracey, 3/13, Digest of Services, 4/17 Dogra, p. 15; author's interviews with Burma veterans.

69 Allen, Burma, pp. 295-96; G. M. Fraser, Quartered Safe Out Here (London: Harper Collins, 1995), p. 190.

70 Fraser, Quartered Safe Out Here, p. 191.

71 Gian Singh, Memories of Friends and Foes (Neath: Cwmnedd Press, 1995), p. 2.

72 John Masters, The Road Past Mandalay (London: Michael Joseph, 1961), pp. 162-63; Slim, Defeat into Victory, pp. 325, 336, 366-67; IWM, 88/48/1, Major H. C. Gay, extracts from his memoirs, p. 122; LH, General Sir Douglas Gracey, 1/5, Appreciation of the Situation on 4 Corps Front, 20 Sept. 1943, points 2 and 3, and 2/24, "Suggestions for Training for and Conducting War against the Japanese for Troops Who have been Fighting in European Theatres of War," par. 1(b) and 6(d); LH, Lt. Col. Donald P. Bryce, 2/3, Operational Memos on Use and Employment of LRP Forces, ch. 9, par. 3(a); NAM, 7304-1-2, Jungle Warfare School Shimoga, Lecture, "The Jap," par. 9.

73 PRO, WO 203/1833, No. 10 Indian Operational Research Section, Operation No. 5, pp. 5051.

74 Cameron, American Samurai, pp. 110-12; Linderman, World within War, ch. 4; OIOC, Mss. Eur B386, Hamilton Simonds-Golding, "Bamboos and Partisans," ch. 6, pp. 1-3.

75 IWM, 80/49/1, Captain N. Durant, account of the second 'Wingate Show,' p. 10. 
was not at all unknown for the Japanese to flee when their positions were overrun. ${ }^{76}$ "the Jap . . can show a good turn of speed when driven out of a position."77 Of one action in which twenty-four Japanese were bayoneted and grenaded in their holes by attacking East African troops, a British officer commented in a letter home, "The odd thing is, after all one has heard [about Japanese fanaticism], that the Japs were absolutely scared stiff and took every possible opportunity of beating it." 78 On other occasions Japanese in positions being overrun would simply stop fighting and wait to be killed by the assaulting British or imperial troops. One report commented they "will often stop fighting and wait for death if our troops use the bayonet and get within fifteen to twenty yards of their positions." 79 A jungle warfare school lecturer told his students that the Japanese held their positions with determination "until attacking [troops] are very close, and then appear to crack up, cowering at the bottom of the trench, waiting to be bayoneted. If he wants the bayonet, so let it be." $" 80$

Simply put, the problem of surrender for troops on both sides was that surrendering was very dangerous if not impossible. Allied soldiers believed, with reason, they would be mistreated or killed if they surrendered. Likewise, Japanese soldiers had every reason to believe that they, too, would be mistreated or killed if they tried to surrender. Depending on the situation, many soldiers on both sides may simply have chosen to go out fighting or take their own lives when confronted with such realities. When a wounded West African soldier was recovered by his unit after two days hiding in the bush, "He explained to his rescuers he had not worried because if his own people found him everything would be all right and if the Japs found him- he startled the doctor by producing a grenade from inside his tunic - he had only to pull the pin and everything would still be all right." 81 No one in this instance had recourse to extraordinary cultural explanations as the man's willingness to blow himself up probably seemed perfectly reasonable to those who found him given the many stories of Japanese mistreatment of prisoners circulating in Allied formations. ${ }^{82}$ The remark of a lone Japanese soldier captured hiding in a village perhaps re-

76 See e.g. Allen, Burma, p. 408; Masters, The Road Past Mandalay, p. 217; LH, Brig. A. B. Gibson, 1/4, Unofficial War History, 2/13 Frontier Force Rifles, p. 46; GM, Loose Archives, 5 RGR, Annexure to R. C. Part I, Order No. 1924, Dated 9 Oct. 1944, Awards-Victoria Cross.

77 GM, G23, Chin Hills Operation Notes and Imphal Operations, Lessons Learnt from Operations in Chin Hills, 24-28 May 1943.

78 IWM, 79/21/1, Brig. K. H. Collen, letter of 30 Sept. 1944.

79 LH, Lt. Col. Donald P. Bryce, 2/3, Operational Memos on Use and Employment of LRP Forces, p. 38 .

80 NAM, 7304-1-2, Jungle Warfare School Shimoga, Lecture, "The Jap."

81 Quoted in John Hamilton, War Bush (Wilby, Norwich: Michael Russell, 2001), p. 71.

82 Japanese mistreatment of prisoners was a common theme both of propaganda and instruction for British and imperial forces. See, for example, NAM, 7304-1-2, Jungle Warfare School, Shimoga, Lecture, "The Jap"; LH, J.A.H. Heard, copies of "Josh" weekly news sheets; Fraser, Quartered Safe Out Here, pp. 44-45. 
flected the wishes of many soldiers in Burma for escape from such dire and limited choices. He told his captors "I want to resign." 83

The problem of surrender in Burma is one example of a feedback loop that increased the intensity of the fighting. Surrendering can act as a 'safety valve' for battlefield violence. A defending force which surrenders in timely fashion, before inflicting heavy casualties on the attacker, might be allowed to do so without severe mistreatment. ${ }^{84}$ However, the more casualties inflicted on the attacking troops, the less likely they will offer quarter. Prohibitions against surrender serve to foreclose exits and intensify the fighting. Jungle terrain also led to intensified combat in Burma. Close terrain meant that engagements often occurred at extremely short ranges and in conditions of surprise, lending them a kill-or-be-killed quality often lacking at longer distances.

Wherever fighting takes on a 'last ditch' no-quarter character, the energies built up can find release in battlefield atrocities ranging from refusal to take prisoners to the massacre, immediately afterwards, of any enemy who do survive. ${ }^{85}$ One Japanese officer in Burma described such situations in this way: "After fierce battles when many comrades were killed, men were excited and felt strong hatred against the enemy soldiers and were provoked to kill even helpless prisoners." 86 Such battlefield processes shaped soldiers' actions on both sides, contributing to an intensifying spiral of savage fighting and atrocity.

Georg Simmel offers a framework for thinking about how the common battlefield context in Burma shaped soldiers' actions on both sides in similar ways. Simmel conceives conflict as a structure shared by the competing parties. ${ }^{87} \mathrm{As}$ a structure, conflict operates to shape the nature of the parties involved in common ways, by for example increasing the internal cohesion of each side. Simmel begins from a sociological premise of human similarity, rather than one of ethnic difference. Humans have similar capacities which can be actualized when they are placed in conflict situations. Particular attributes and actions of the parties to a conflict emerge conjuncturally in the conflict situation itself and are not necessarily the product of some pre-existing social or cultural characteristic of one or another of the parties, but rather are effects of the structural relations at work.

Such an analytic move need not involve denying the differences in the cultural and military backgrounds of the soldiers who found themselves at war in Burma. These certainly played a role in shaping the structure of the conflict. But Simmel suggests how it is that soldiers from remarkably different back-

83 Hamilton, War Bush, p. 300.

84 Dave Grossman, On Killing (Boston: Little, Brown, \& Co., 1995), pp. 199-201; Linderman, World within War, pp. 124-30. See also Tony Ashworth, Trench Warfare 1914-1918 (London: Pan Books, 2000).

85 Linderman, World within War, pp. 177-84; Charles Sydnor, Soldiers of Destruction (Princeton: Princeton University Press, 1990), pp. 101-9.

86 Nunneley and Tamayama, eds., Tales by Japanese Soldiers, p. 162.

87 Georg Simmel, Conflict and the Web of Group-Affiliations (New York: The Free Press, 1955). 
grounds might come to behave in remarkably similar fashion. As Cameron observed of the U.S. marines on Guadalcanal, "the way in which the cultural values of the enemy, so often portrayed as alien to the West, were matched among the marines is striking." 88 The battlefield was the site of an interactive game in which if one side 'upped the ante,' so to speak, by refusing to surrender or take prisoners, the other side had to respond in some fashion. The commander of the marines on Guadalcanal remarked of the Japanese "These people refuse to surrender . . . You can readily see the answer . . . war without quarter." 89 Such interactions formed a common structure which then exercised its own influence on the fighting. Resisting to the 'last man, last round' in Burma and elsewhere is not necessarily evidence of some extraordinary individual motivation or of ideological indoctrination. It can also be a very human and understandable response to a harsh situation. That such last-ditch resistance serves to evoke a similar response from the enemy points to the existence of the self-generating dynamics of battlefield violence, and hence to the value of the kind of structural approach being suggested here. As Clausewitz remarks, "Each side . . compels its opponent to follow suit; a reciprocal action is started which must lead, in theory, to extremes." 90

It is important to emphasize the constraints on agency from the perspective of the individual soldier revealed by the problem of surrender and other common battlefield situations in Burma, such as the defense of an all-round perimeter. These had to be defended vigorously, since a breach could mean the collapse of the entire position. Soldiers failing to do so faced the prospect of being overrun, bayoneted or grenaded in their holes, or falling into the hands of an enemy known to mistreat prisoners. As a result, more than a few of the twenty Victoria Crosses earned by Indian soldiers in Burma were awarded for the valiant defense of a perimeter. Veteran officers and men understood the realities of perimeter defense and, for those who could overcome their fear, these were reason enough to fight with grim determination. Jemadar Parkash Sing of the $14 / 13^{\text {th }}$ Frontier Force Rifles was wounded four times before expiring as he and his men struggled to hold their section of a perimeter and evict the Japanese who had gotten in. ${ }^{91}$ Not only do such examples illustrate the importance of primary group theory's central insight_-fighting for group survival in conditions of mortal danger - but they also point to the very limited options available. Any course of action other than vigorous defense made it that much more likely the position would be overrun and one would meet one's end at the point of a Japanese bayonet.

This discussion has conceived battle as a structure, formed by the interaction of both sides and shaping participants and their actions in important ways. Bat-

88 Cameron, American Samurai, p. 104.

89 Quoted in Linderman, The World within War, p. 161.

90 Carl von Clausewitz, On War (Princeton: Princeton University Press, 1976), p. 77.

91 IWM, 96/8/2, Col. E. C. Pickard, Parkash Sing's VC citation. 
tle is more than simply an armed clash between two culturally distinct, preformed opponents. In Ernst Jünger's phrase, it is "a condition of things." 92 As with all structures, analysts must exercise caution in assessing the narrations and representations offered by agents caught up in them. The reasons for such caution derive in part from the always problematic relation between structure and representation, as structures are to greater or lesser degree opaque to the agents shaped and formed by them. In the case of battle, there are additional considerations, arising from the enormous stress and the extraordinary psychic energies involved. Representations of battle by participants are often attempts to come to terms with their experiences and actions and to make some meaningful sense of the absurdities of war. Whether in the form of letters, memoirs, interviews, or official documents, such representations cannot be taken at facevalue. Yet, neither military history nor sociology has devoted significant attention to just how such evidence of 'the face of battle' should be interpreted. What follows is an attempt to sketch out how to think about British and imperial representations of racial antagonism in the Burma campaign as well as the place of race hate in battle more generally.

$$
\text { “Why Fight Japan?"93 }
$$

In what was known as "political India"-intellectuals, politicians, and articulate urban opinion-there were conflicting views regarding Japan. Some sympathized strongly with the Allied cause, while others held Japan in high regard as an independent Asian power or saw in the war an opportunity for Indian independence. But "political India" stood at some distance from the army regulars as well as the mostly illiterate and uneducated peasants who would volunteer for service during the war. Any consideration of the role and nature of racial antagonism among imperial troops must begin with an account of their capacity to understand the ostensible political identities and purposes at stake in the war they fought in.

According to one estimate, 90 percent of Indian recruits were illiterate on joining the forces. ${ }^{94}$ In 1943, 82 percent of infantry recruits in the Indian Army were illiterate. ${ }^{95}$ The soldiers who filled out the ranks of the infantry battalions were for the most part from isolated peasant communities and had very little in the way of education until their military service. The situation was not much different in East and West Africa. Educated imperial recruits were far more likely to be sent into the technical, non-combat branches of service. The men who did the fighting, therefore, began the war with very little knowledge of Japan or Burma or the scope and nature of the war.

Carfrae describes using a map to give orientation lectures to his Nigerian

92 Ernst Jünger, The Storm of Steel (New York: Zimmerman and Zimmerman, 1985), p. 109.

93 The title of a pamphlet produced for British troops in the Far East by the Directorate of Army Education, NAM, 1945 (59).

94 OIOC, L/WS/1/1506, India Command Weekly Intelligence Summaries, untitled note inserted in file.

95 OIOC, L/WS/1/1371, Report of Infantry Committee. 
troops. "This is where the Germans live. Here is Italy, there France . . "96 Carfrae had trouble keeping the men awake for these affairs. In the Indian Army one morale official noted, "it is only the small number of educated [men] who can have any real appreciation of the development of the war as a whole."97 In 1943, officers responsible for propaganda and information for Indian troops realized that " 'extensive propaganda, in a geographical sense,' was too complicated for the average Indian soldier to assimilate." 98 The fighting troops simply lacked the necessary education and breadth of experience.

As useful as illiteracy was from the perspective of imperial control, insulating soldiers in part from nationalist politics, by the Second World War even infantry combat had become highly technical. Imperial militaries had to become vast centers of education. ${ }^{99}$ Education was double-edged from the point of view of the imperial authorities, since soldiers had access to ever more information which could not be entirely controlled by the military. In part as a consequence of these developments, army information and propaganda policies became an important aspect of the war effort. ${ }^{100}$

In the Indian Army, in the wake of the retreat from Burma in 1942, there was great concern about 'defeatism' among the men, and a determined effort to develop a degree of political commitment to the war was undertaken. It took the form of the "Josh" system. "Josh" means "pep," "spirit," or enthusiasm in Urdu. The basic idea was for specially trained officers in each unit to meet informally with small groups of troops to discuss the war. A range of propaganda publications for Indian troops were produced, and "Josh" officers were briefed on the lines they were to take with the men. In the words of an instruction pamphlet for "Josh" officers, the purpose was to "build in every Indian soldier the knowledge and firm faith that the Japanese and everyone who represents the Japanese are his own personal enemies."101

Atrocity propaganda played an important role. Various Japanese horrors committed against Indian soldiers or Indian expatriates in Japanese-occupied areas were described to the men in publications or talks. Prominence was given to the rape of Indian women and Japanese disrespect for Indian religions, often combined as when Indian women were reported to be raped inside places of worship. ${ }^{102}$ Propagandists invented conflicts between Indian cultural and religious practices and the Japanese. Hindu soldiers, for example, were told that

96 IWM, 80/49/1, Charles Carfrae, “Dark Company,” p. 56.

97 OIOC, L/WS/2/71, Morale Reports, Aug., Sept., and Oct. 1944.

98 Sanjoy Bhattacharya, “A Necessary Weapon of War.” Ph.D. Dissertation, School of Oriental and African Studies, University of London (1996), p. 68.

99 Parsons, The African Rank-and-File, p. 115; Perry, The Commonwealth Armies, p. 112; OIOC, L/WS/1/1506, India Command Weekly Intelligence Summaries, untitled note inserted in file.

100 Bhattacharya, "A Necessary Weapon of War."

101 OIOC, L/WS/1/1576, INA and Free Burma Army, "Instructions on Josh Work and Josh Group Organisation within Units."

102 Bhattacharya, "A Necessary Weapon of War," p. 68. 
the Japanese were cruel to cattle and that they desecrated temples. ${ }^{103}$ Other variations included Sikh POWs being forced to shave their beards and cut their hair or Hindu or Muslim troops being forced to handle or eat beef or pork, respectively. ${ }^{104}$ Indian soldiers passing through the $14^{\text {th }}$ (Training) Division, gathered in small groups, were asked "Did you know that Jap fathers sell their daughters into brothels and that this is a widespread custom in Japan?"105

The extent and the effectiveness of the "Josh" system and other propaganda efforts is unclear. Sanjoy Bhattacharya emphasizes the significance, in maintaining Indian Army morale, of information on material benefits available to soldiers and their families, as against "atrocity propaganda."106 One intelligence report noted "trying to make [Indian Army soldiers] hate Jerry or the Jap is somewhat artificial." 107 When some of the "Josh" propaganda lines were described to one former officer, he quipped "I would have thought my sepoys were smarter than that." 108 More generally, there is no reason to think that Indian frontline troops differed from other combat soldiers in their reaction to "hate the enemy' style propaganda. As other scholars have commented, efforts to arouse hatred of the enemy and enthusiasm for the war effort are most effective on the homefront. ${ }^{109}$ Soldiers on active duty are typically skeptical of official propaganda and have far more immediate concerns. One report on British soldiers in India noted they are "extremely suspicious of lectures and instructions on Current Affairs. It all sounds like official 'dope.'”110

In their ignorance of Japan and the politics of the Far Eastern War, Indian soldiers were not so very different from British ones. A report on British infantry in India noted, "Before the sudden entry of Japan into the war, the average British soldier knew little or nothing of the Japanese."111 Yet many British soldiers developed an intense hatred of the Japanese during the course of the war. ${ }^{112}$ The report just quoted, written in 1943 by a committee of experienced infantry commanders, goes on to note that "while there is nothing wrong with the determination of the British Infantry soldier to fight and kill the Jap," it is only among those units which have already seen action that there is significant animosity towards the Japanese. ${ }^{113}$

103 LH, J.A.H. Heard, "Josh," Nos. 2, 3, and 6.

104 Bhattacharya, “A Necessary Weapon of War," p. 68.

105 IWM, P140, Major General A. C. Curtis, Report on $14^{\text {th }}$ Indian Division July 1943-November 1945, p. 9.

106 Bhattacharya, “A Necessary Weapon of War,” p. 75.

107 OIOC, L/WS/1/317, India Monthly Intelligence Summary, No. 13, 5 Jan. 1943.

108 Author's interviews with Burma veterans.

109 L. L. Farrar, "Nationalism in Wartime," in F. Coetzee and M. Shevin-Coetzee, eds., Authority, Identity and the Social History of the Great War (Providence: Berghahn Books, 1995); Paul Fussell, Wartime (Oxford: Oxford University Press, 1989); Linderman, World within War, ch. 8.

110 OIOC, L/WS/1/1506, India Command Weekly Intelligence Summaries, 22 June 1945.

111 OIOC, L/WS/1/1371, Report of Infantry Committee, 56(a). See also Shipster, Mist Over the Rice Fields, p. 4.

112 Author's interviews with Burma veterans.

113 OIOC, L/WS/1/1371, Report of Infantry Committee, 56(a). 
That racial and other hatred of the enemy was a product of and not an input to the fighting, at least initially, appears to have been the case for Indian troops as well. Many did develop racist and even exterminationist attitudes towards the Japanese once they were on campaign in Burma. While in 1943 a report noted "there still existed a patent lack of basic conscious enmity amongst Indian troops toward the vaguely comprehended 'Jap,' the increasing bitterness of the fighting began to produce its own effects. ${ }^{114}$ One Indian soldier wrote home in late 1944 or early 1945, “The Japs are most uncultured and cruel . . . They have got beastly characteristics. Such a nation should be totally destroyed for the good of the world." 115 In the wake of successful Allied offensive operations to re-enter Burma, a morale report noted that, "First-hand experience of the enemy's cruelty to the occupied populations has bred a genuine hatred of the Japanese." "116 An NCO exclaimed of the Japanese in a letter home, "May God bring destruction to this oppressor nation."117 A VCO reached somewhat unsuccessfully for world historical language to describe the meaning of the war: "This war raised by two brutal nations of the world challenges every human race to fight against it in connection to save the human culture, morale, civilisation, and what not." 118 Other Indian soldiers turned to the insect analogies which were widely used to describe the Japanese. An Indian major, mixing the ovine with the entomological, described the Japanese withdrawal after the defeat at Imphal in these terms: "Then happened ridiculous incidents when the rabble started withdrawing and every [company] like mine would see by first light hundreds of sheep like Japs trying to get past our positions where we had every infantry weapon sited ... even the [company commander] would push the bren gunmen aside and enjoy killing the Japs like insects, brutal ..."119

While sentiments such as these reflect a willingness and even desire to fight the Japanese, it would be difficult to account for them by long-standing racism in soldiers' social contexts or by reference to political ideology. Anti-Japanese racism among Indian soldiers developed in the course of the fighting; their use of Allied justifications for the war were likewise occasioned by their experience of the war itself. To the extent they did, most Indian soldiers arrived at answers to the question, "Why fight Japan?" only after they had already been doing so. Once developed, such race hate could certainly intensify the cycle of savage fighting. Stories of enemy atrocities functioned as self-fulfilling prophecies, inspiring brutalities reciprocated by the other side.

A language of race hate, whether made available through official propagan-

114 OIOC L/WS/1/1576, INA and Free Burma Army, Memorandum on the work done by the P. R. Central Group and its future, 10 Nov. 1943.

115 PRO, WO 203/2355, ALFSEA Morale Reports, Nov. and Dec. 1944, and Jan. 1945, p. 15.

116 OIOC, L/WS/2/71, Morale Reports, Nov. 1944-Jan. 1945.

117 Ibid. 118 Ibid.

119 OIOC, L/PJ/12/656 Middle East Censorship Fortnightly Summary Covering Indian Troops, 14 June-27 June 1944. 
da or derived from more general cultural resources, became salient for soldiers once they were caught up in the fighting. Racist constructions of the Japanese served in part as an outlet for anger at the unbearable situation that, it was believed, the Japanese had created by fighting with such determination. The processes of othering involved were in large measure generic to the campaign and battlefield. They did not require a pre-war, civilian social context of virulent racism or other radical alterity directed at some specific enemy. The fact that combat soldiers fall back on such representations when narrating their experience does not mean racism was their 'real' motivation in any straightforward sense. It simply means that soldiers made use of available stereotypes when narrating their situation and describing their conduct. The ultimate determinants of the structure of battle remained more or less opaque to them.

A final example of the relation of racist representations to battlefield experience is helpful. A variety of analogies were often made between Japanese soldiers and various animals and insects, as in "fanatical little rats." ${ }^{120}$ Slim himself was fond of an ant analogy: "The Japanese were ruthless and bold as ants." ${ }^{121}$ He told his officers, "Picture yourself fighting man-size red ants ... [the Japanese have] all the qualities and faults of the fighting ant."122 While certainly such a description draws on Occidental images of the Orient, it is also rooted in the experience of fighting in Burma. The Japanese constructed elaborate bunker systems often connected by tunnels. Due to Allied air and artillery superiority, they had to dig deep to survive and very often fought and died in their holes, facilitating ant-like, rat-like and other such analogies. Additionally, the Japanese failed to vary many of their tactical doctrines and procedures, lending further weight to the notion of a colony of ants that has fixed ways of going about things, and is consequently vulnerable; hence the notion that the Japanese can be stomped on and killed like ants. ${ }^{123}$ A colony of ants also captures the Allied experience of the Japanese as both highly modern and organized but also as primitive and brutal. Thus the use of such analogies was in a strong sense appropriate to the context in which British and imperial soldiers were fighting. They served to orient officers to features of Japanese tactics and provided a language to describe battlefield phenomena. Those weary, hungry, diseased and defeated Japanese the Indian major quoted above saw pulling out of Imphal really were as sheep, who then fell like flies under his fire. Even in an obvious case of the use of Orientalist and racist imagery — an Asian army of ants - it is

120 Major M. A. Lowry, An Infantry Company in Arakan and Kohima (Aldershot: Gale and Polden, 1950), p. 51; IWM, 88/48/1, Major H. C. Gay, extracts from his memoirs, p. 127; IWM, 79/ 21/1, Brig. K. H. Collen, letter of 12 Dec. 1944; LH, Major General W. A. Dimoline, IX/1-2, 11 (EA) Division Training Instruction No. 13, par. (f).

121 Slim, Defeat into Victory, p. 537; see also pp. 239, 381, 485.

122 OIOC, L/WS/1/778, Infantry: GHQ(I) Infantry Liaison Letters, Jungle Fighting in Burma, Appendix A, No. 14, 15 Jan. 1945.

123 Slim, Defeat into Victory, p. 485; OIOC, L/WS/1/778, Infantry: GHQ(I) Infantry Liaison Letters, Jungle Fighting in Burma, Appendix A, No. 14, 15 Jan. 1945. 
contextual features that make that imagery particularly salient and widespread, allowing it to play a role in shaping the fighting.

This section has elaborated the notion of battle and campaigning as sets of structural relations generative of battlefield conduct and of representations of racial antagonism. It outlined some aspects of the structurally determining character of the battlefield and how apparently 'fanatic' behavior, such as preferring suicide over capture, might become reasonable for anyone caught in a similar situation. When soldiers come to narrate their experiences, they can only do so by drawing upon the cultural resources available to them. British and American soldiers possessed a rich stock of anti-Asian stereotypes to make use of in representing their experiences in the war against Japan. Official propaganda reinforced and revived these stereotypes and made them available to imperial troops. It is unsurprising that soldiers made use of these resources, providing much evidence for the ethnic war complex. But each such narrative is a window on a structural context shared with the enemy, rather than the last word on soldiers' 'real' motivations.

\section{CONCLUSION: ETHNICITY, HUMANITY, AND WAR}

Much of history is narrated as the story of clashing nation-states. In this story, war and national identity become closely linked for scholars as well as more popularly. Benedict Anderson, for example, finds in the "limited imaginings" of nationalism the reasons "for so many millions of people ... willingly to die." 124 There is more than a little here of the primordialism and reductionism Anderson so effectively critiques elsewhere. As Appadurai remarks, "In many of these theories of the nation as imagined, there is always a suggestion that blood, kinship, race and soil are somehow less imagined and more natural than the imagination of collective interest or solidarity." 125 National war stories do powerful imaginary work in conjoining 'dulce et decorum' with 'pro patria.'

The ethnic war complex critiqued above is less an explicit scholarly discourse and more an uncritical, common sense understanding of how energies for war are mobilized, one in which ethnic or national identities serve as 'unmoved movers' of the organization and use of force. In the preceding discussion, as here, there has been some conflation of ethnicity and nation. Both are, however, forms of group identity easily conjured as the driving forces behind wartime violence. Such imaginings seem so natural because wars, and representations of sacrifice in war, are engines of reification. ${ }^{126}$ They help instantiate an image of the world as composed of ethnic groups, nations and their homelands, a geography of war and identity. In circular fashion, war and other violent conflict then can be interpreted as a confrontation between reified ethnic groups

124 Benedict Anderson, Imagined Communities (London: Verso, 1983), p. 16.

125 Appadurai, Modernity at Large, p. 116.

126 Elaine Scarry, The Body in Pain (Oxford: Oxford University Press, 1985); Jay Winter, Sites of Memory, Sites of Mourning (Cambridge: Cambridge University Press, 1995). 
or nations. War plays an important role in what Akhil Gupta and James Ferguson term "cultural territorializations," the contingent social and historical processes through which peoples, places, and cultures come to be associated with one another. ${ }^{127}$

The ethnic war complex essentializes these "cultural territorializations" and reads them back into our accounts of war and the making of wartime violence. This process is most obviously visible in contemporary accounts of 'ethnic conflict' in former Yugoslavia or Africa, but it is also apparent in the emphasis placed on nationalism and racial ideology in analyses of metropolitan warfare. Soldiers' battlefield and other behavior, in particular their willingness to commit atrocity, is said to reflect national racial prejudice. War becomes a confrontation between reified ethnic groups or nations, rather than a form of social interaction through which identities are made and re-made. "It is," as John Comaroff remarks, "in situations of struggle and times of trouble that the content of ethnic self-consciousness is (re)fashioned." 128

In contrast to the ethnic war complex, this essay situated constructions of self and other within organizational and structural context. Ethnic relations were shaped and conditioned by military organization and wartime experience. The radical alterity evinced in representations of battle in Burma was a product of military and battlefield processes, rather than an essential input into wartime savagery. A sketch of the cultural constitution of military force and the social making of battle was offered, one which did not rely on essentialized ethnic differences or antagonisms. As such, this essay seeks to contribute to the critical study of war and the military.

It aims to contribute in a small way as well to the growing reflexivity in the human sciences concerning their Eurocentric origins and governing assumptions. For the ethnic war complex, humans are fundamentally distinguished on the battlefield by their ethnicity. More generally, (some) Western and especially 'democratic' soldiers are often differentiated sharply from, say, Nazi or Japanese soldiers, who are seen as different kinds of creatures. ${ }^{129}$ "We were rational Europeans, not fanatics," intoned Carfrae the Chindit commander after describing the kill-or-be-killed nature of the fighting in Burma, "therefore how could we be expected to behave in such a way?"130 But British and imperial soldiers did come to behave that way in many respects. In significant measure, what is at issue are more general human capacities, rather than particular ethnic, national, or 'civilizational' identities. Emile Durkheim's reminder to his fellow Europeans that even the most savage of the savages has something to

\footnotetext{
127 Akhil Gupta and James Ferguson, "Culture, Power, Place," in A. Gupta and J. Ferguson, eds., Culture, Power, Place (Durham: Duke University Press, 1997), p. 4.

128 John Comaroff, "Humanity, Ethnicity, Nationality," Theory and Society 20, 5 (1991), p. 670.

129 Hanson, Carnage and Culture; Dan Reiter and Allan Stam, Democracies at War (Princeton: Princeton University Press, 2002), ch. 3.

130 IWM, 80/49/1, Charles Carfrae, "Dark Company," p. 128.
} 
PEOPLES, HOMELANDS, AND WARS? I63

teach us about humanity qua humanity is appropriate: "The most barbarous and the most fantastic rites and the strangest myths translate some human need, some aspect of life, either individual or social." ${ }^{131}$ Analyses of wartime violence need to take this turn to human commonality, rather than continuing to emphasize ethnic difference.

131 Emile Durkheim, The Elementary Forms of the Religious Life (New York: The Free Press, 1965), p. 14. 